\title{
Raising the standards by standardization?
}

\author{
Uwe Gellert ${ }^{1}$
}

Published online: 6 September 2021

(C) The Author(s) 2021

It is commonplace to say that the world has become more and more the same, a global village in which differences between countries and between regions disappear. Of course, this is true, and at the same time it is wrong. We are all affected by climate change, but the consequences vary across the globe. Billions of people have access to internet, although far from everybody, and that brings us closer to each other, but again, the internet is used in many different ways. It is important to note, here, that such processes do not simply occur but that they are made by us and, thus, could be avoided or altered in myriad ways. What about education? Shouldn't we make it more similar all over the world, too? There is a long tradition of "Mathematics for All," which is concerned with cultural selectivity and unequal distribution of mathematics education worldwide (e.g. Damerow et al., 1984; cf. Gellert, 2017). These concerns range from access rates to mathematics education, to issues of quality curricula and their implementation.

A substantially different strategy for making mathematics education similar across countries can be observed in bodies such as the International Association for the Evaluation of Educational Achievement (IEA) and, more specifically, the Organisation for Economic Co-Operation and Development (OECD). The key, here, is measurement, particularly what is measured and how. The Third International Mathematics and Science Study (TIMSS 1995), administered by IEA, used mathematics content that is present in every participant country's curriculum to measure knowledge and skills-thus drawing on what is already similar across the countries. In contrast, the Programme for International Student Assessment (PISA), administered by OECD, defined mathematical competencies that students of a certain age should be able to show. It did not care for similarities or differences; it simply tried to produce similarities by setting standards of what is important in international comparative surveys. And, apparently, OECD's strategy is successful: British mathematics educators look to China (Yuan \& Huang, 2019), Chilean mathematics education adopts the "Singapore method" (Barbé, Espinoza, \& Gellert, under rev.), while Chinese curriculum reform includes "Western" pedagogies ( $\mathrm{Li} \& \mathrm{Li}, 2018$ ), and so on. The more similar the mathematics curriculum across countries, the easier the comparative assessment. In addition, not only differences between countries, but also within each country are at stake. School and life realities differ between urban and rural areas, between affluent and underprivileged milieus. How is this recognized in standardized curricula? What are the effects of such a standardization? Who benefits? While political and administration agents

Uwe Gellert

uwe.gellert@fu-berlin.de

1 Freie Universität Berlin, Berlin, Germany 
might appreciate universal standards and measures, for some local mathematics teachers these universal standards tend to threaten their elaborate local curricular and pedagogical practice.

Let us now move to mathematics teacher education and to the research articles of which this volume consists. How do the four contributions engage with improving mathematics teacher education practice, with raising standards, or with standardization?

Actually, it was Tiffany Jacobs's and Susan Swars Auslander's paper “Understanding a high stakes teacher performance assessment in mathematics through elementary prospective teachers' lived experience" that motivated me to focus this editorial on standardization and standards. "edTPA ${ }^{\circledR}$ is a performance based assessment process designed by educators to answer the essential question of whether teachers are ready for the job" (www.pearsonass essments.com; TPA is the abbreviation for Teacher Performance Assessment). As Jacobs and Auslander point to, edTPA is a high-stakes assessment, with "18 [US] states adopting it for licensing new teachers or actively considering this step" (Jacobs \& Auslander, this issue). In edTPA, preservice teachers submit written descriptions, lesson plans, reflections, commentaries to analytic prompts, as well as video clips to Pearson, pay a $\$ 300$ fee, and temporary workers at Pearson, paid about $\$ 75$ per exam, score each portfolio. There can be no doubt that only a strict, rigorously standardized and sufficiently simple scoring scheme can facilitate the verdict whether a teacher is "ready for the job" (see above). This is really high stakes. In their contribution, Jacobs and Auslander report on the experiences of preservice teachers with edTPA. These preservice teachers struggle with standards and assessment criteria that they find difficult to respond to in their local classrooms. They focus their attention on fulfilling what the assessment supposedly asks them to do, and de-focus from becoming a skilled teacher. As the standardization of edTPA requires mentors and teacher educators to deny too much assistance, learning to teach becomes a lonesome process, which in the end is at risk of becoming uniform, and detached from the variety of realities in classrooms.

When research in mathematics teacher education is interested in the development of mathematics teachers' knowledge, it nearly always references a distinction between (prospective or practicing) teachers' mathematical knowledge and pedagogical content knowledge (PCK). In terms of the recognition and the professional qualification of teachers, Shulman's emphasis on a specialized body of teachers' knowledge, PCK, was highly important and influential. In terms of research on mathematics teachers' CK and PCK, Shulman's introduction of PCK served, and still serves, as theoretical ground for hundreds of studies during the last 20 years. It should not be forgotten that a long-standing tradition of thinking about the unique knowledge of mathematics teachers has been developed on the other side of the Atlantic (e.g. Felix Klein's Elementary Mathematics from a Higher Standpoint, didactique/didaktik/Didaktik), part of which is concerned with analyzing the connectedness of CK and PCK rather than separating these two for analytical or curricular purposes. However, research on mathematics teachers' professional knowledge has led to questions such as, how much CK and PCK is required/beneficial for which teachers, how does CK and PCK develop during teacher formation? In this volume, Sofie Agathangelou and Charalambos Charalambous report on results of their empirical investigation, "Is content knowledge pre-requisite of pedagogical content knowledge?" In the context of standardization, it is interesting to observe how CK and PCK are operationalized in test items. Do researchers in this field agree about how to measure, for example, the content knowledge of mathematics teachers? If not, then there is a "risk of producing mixed or even conflicting results" (Agathangelou \& Charalambous, this issue). It might make a difference for relating CK and PCK whether CK is tested by the item "Find a fraction that lies in between 
1/8 and 1/9" (Agathangelou \& Charalambous, this issue) or "Is $2^{1024}-1$ prime?" (Krauss et al., 2004, p. 41; translation UG). What can be observed here is the dense entanglement of measurement and standardization.

The article "Analysis of the final comments provided by a knowledgeable other in lesson study" by Tatsuhiko Seino and Colin Foster is also related to globalized teacher education practices in the aftermath of TIMSS and the TIMSS Video Study. It is about the difficulties that educators outside Japan experience when trying to implement Japanese lesson study for the purpose of raising the standards of teaching. It argues that lesson study cannot be successfully adopted in case the role of post-lesson discussion with a koshi is not taken sufficiently into account. The koshi is a knowledgeable other in terms of the didactical details of a broad range of mathematical content and methods. As Seino and Foster emphasize, the koshi knows that "'the devil is in the detail"" (this issue) and engages the participants in in-depth discussion of these didactical details. What the koshi does can be considered contrary to standardization: while practices such as edTPA ruthlessly ignore the situatedness of the teaching and learning of mathematics in classrooms, post-lesson discussions within Japanese lesson studies aim at relating the koshi's (personal) knowledge to the specifics of the classroom that is the joint focus of attention.

Finally, in "Prospective teachers' analysis of a mathematics lesson: examining their claims and supporting evidence," Christine Phelps-Gregory and Sandy Spitzer draw attention to prospective mathematics teachers' ability to analyze student thinking. The study is rich in detail, and it illustrates the intricacies of relating group characteristics of prospective teachers to their performance in task-based surveys. For elementary versus secondary prospective teachers, for those who had versus had not completed a methods course, for those who had versus had not taken at least three courses of mathematical knowledge for teaching, the individual variation between prospective teachers is shown to be much larger than the group differences. Is this result an artifact of the study design, or is it a plea for looking more carefully at how individual prospective teachers develop professional knowledge?

To conclude, it is of course important to compare. For most research methodologies, comparison is an implicit or explicit principle: what distinguishes A from B, why does $\mathrm{C}$ work better than $\mathrm{D}$, why does $\mathrm{E}$ work under condition $\mathrm{F}$ but not under condition $\mathrm{G}$, etc.? However, this point is less straightforward and more problematic when comparison is serving the aim of making things equal despite situational singularity, or when things are necessarily conceived, or made, equal, theoretically or practically, before measurement and comparative analysis can be started. In that sense, we, as mathematics educators and researchers, should be aware of the double-edged-sword characteristic of standardization, not always directed at improvements in mathematics teacher education, and sometimes contradicting the methodological standards of our research endeavors.

Funding Open Access funding enabled and organized by Projekt DEAL.

Open Access This article is licensed under a Creative Commons Attribution 4.0 International License, which permits use, sharing, adaptation, distribution and reproduction in any medium or format, as long as you give appropriate credit to the original author(s) and the source, provide a link to the Creative Commons licence, and indicate if changes were made. The images or other third party material in this article are included in the article's Creative Commons licence, unless indicated otherwise in a credit line to the material. If material is not included in the article's Creative Commons licence and your intended use is not permitted by statutory regulation or exceeds the permitted use, you will need to obtain permission directly from the copyright holder. To view a copy of this licence, visit http://creativecommons.org/licenses/by/4.0/. 


\section{References}

Barbé, J., Espinoza, L., \& Gellert, U. (under review). Modifications of the mathematics curriculum over the last two decades in Chile: effects on school mathematical practice.

Damerow, P., Dunkley, M. E., Nebres, B. F., \& Werry, B. (Eds.). (1984). Mathematics for All: Problems of Cultural Selectivity and Unequal Distribution of Mathematical Education and Future Perspectives on Mathematics Teaching for the Majority. UNESCO.

Gellert, U. (2017). Revisiting mathematics for all: A commentary to Pais's critique. In H. Straehler-Pohl, N. Bohlmann, \& A. Pais (Eds.), The Disorder of Mathematics Education: Challenging the Sociopolitical Dimension of Research (pp. 67-87). Springer.

Krauss, S., Kunter, M., Brunner, M., Baumert, J., Blum, W., Neubrand, M., Jordan, A., \& Löwen, K. (2004). COACTIV: Professionswissen von Lehrkräften, kognitiv aktivierender Mathematikunterricht und die Entwicklung von mathematischer Kompetenz. In J. Doll \& M. Prenzel (Eds.), Bildungsqualität von Schule. Lehrerprofessionalisierung, Unterrichtsentwicklung und Schülerförderung als Strategien der Qualitätsverbesserung (pp. 31-53). Münster: Waxmann.

Li, H., \& Li, N. (2018). Features and characteristics of Chinese new century mathematics textbooks. In Y. Cao \& F. K. S. Leung (Eds.), The 21st Century Mathematics Education in China (pp. 171-192). Springer.

Yuan, H., \& Huang, X. (2019). China-England mathematics teacher exchange and its impact. Frontiers of Education in China, 14(3), 480-508.

Publisher's Note Springer Nature remains neutral with regard to jurisdictional claims in published maps and institutional affiliations. 